Original scientific paper - Izvorni znanstveni rad

UDK: 579.864.1/637.35'63

\title{
Indigenous strains of Lactobacillus isolated from the Istrian cheese as potential starter cultures
}

doi: 10.15567/mljekarstvo.2016.0404

\author{
Nataša Hulak, Ana Žgomba Maksimović, Ana Kaić, Andrea Skelin, Mirna Mrkonjić Fuka* \\ University of Zagreb, Faculty of Agriculture, Department of Microbiology, \\ Svetošimunska 25, 10000 Zagreb, Croatia
}

Received - Prispjelo: 30.10.2015. Accepted - Prihvaćeno: 20.10.2016.

\begin{abstract}
Istrian ewe's milk cheese is an autochthonous product that is manufactured for generations on small family farms in the Croatian peninsula Istria. Traditional Istrian cheese is made from unpasteurized ewe's milk, without the addition of starter cultures. Consequently, the specific flavour and texture of the Istrian cheese is owed to metabolic processes of indigenous microflora of which Lactobacillus species play pivotal role. Characterisation and selection of indigenous lactobacilli may result in the potential use of selected strains as starter, bioprotective or even probiotic cultures. This study focuses on potential use of Lactobacillus plantarum and Lactobacillus casei isolated from traditional Istrian cheese as starter cultures, by using methods that determine their proteolytic, lipolytic, antimicrobial and haemolytic potential, as well as their ability of acidification, autoaggregation and survival in simulated gastrointestinal conditions. Our results indicated that from 12 representative strains most revealed a low or moderate proteolytic activity as well as absence of lipolytic and haemolytic activities. From 12 strains, 5 of them showed a medium to strong acidification ability and lowered the pH of milk below 5.00 after 24 hours of incubation. Furthermore, almost all isolates exhibited antimicrobial activity against Serratia marcescens, and lowest number of isolates showed antimicrobial activity against Staphylococcus aureus and Listeria innocua. The studied Lactobacillus strains revealed high survival rate in a simulated oral cavity and duodenum conditions, while the survival ability in a simulated gastric conditions was much lower. Ability to aggregate was low for all tested strains, after 3 hours and after 5 hours of incubation.
\end{abstract}

Key words: Istrian cheese, Lactobacillus spp., starter cultures, antimicrobial activity

\section{Introduction}

Traditional Istrian cheese is produced from raw ewe's milk, which is obtained from autochthonous sheep called Pramenka that is breed in Istria (Mulce et al., 2011; Mioč et al., 2012). This cheese is characterized by its unique flavour and texture that derives from the usage of raw sheep milk without the addition of starter cultures. Therefore, its specific characteristics rely on metabolic processes of indigenous microbiota, mostly lactic acid bacteria (LAB) of which lactobacilli play the pivotal role. Lactobacilli are non-sporulating, gram positive, catalase negative rod-shaped bacteria and coccobacilli tolerant to low pH (Claesson et al., 2007; Sieladie et al., 2011). They may be naturally present in milk as falling within the natural microflora of milk (Wouters et al., 2002) and are dominant during the ripening of many artisan cheeses. The technological role of LAB in fermented milk is their ability of acidification (Mäyrä-Mäkinen and Bigret, 2004) and the development of flavour and texture due to processes 
such as metabolism of lactose, lactate, citrate, proteins and lipids. A large number of LAB species, produce lactic acid by taking advantage of various carbohydrates, consequently forming a part of the microorganism present in the human and animal digestive tract. Among LAB, certain strains are used as probiotics in food and pharmaceutical industries. Classified as beneficial for their hosts, probiotics represent an increasing potential in production of varied type of foods. The most commonly used probiotics belong to the species of Lactobacillus, Bifidobacterium and Streptococcus. Apart from the impact on the flavour and texture of cheese, LAB produce bacteriocins that can inhibit not only closely related species but a broad-spectrum of bacteria (Fox et al., 2004). This is well characterized for Lactobacillus species as e.g. Lb. casei, Lb. paracasei, Lb. plantarum and Lb. curvatus (E1 Soda et al., 2000; Vasiee et al., 2014).

Since technological and probiotic potential of lactobacilli isolated from the Istrian cheese has not been investigated, it was necessary to thoroughly evaluate their desirable properties, their biotechnological and probiotic potential and assessed their potential application as microbial cultures for the purposes of traditional or industrial cheese production.

Thus, the objectives of this work were to determine qualitative variability of the technological and probiotic potential of 12 cheese strains previously molecularly confirmed as Lactobacillus casei or Lactobacillus plantarum. The isolates were verified for their proteolytic, lipolytic, haemolytic and acidification activity. Their probiotic potential was assessed in GIT simulated conditions (oral cavity, stomach and intestine). All isolates were tested for their autoaggregation potential as well as for antimicrobial activity against seven types of potential spoilage or pathogenic species commonly found in food.

\section{Material and methods}

\section{Lactobacillus isolates}

Twelve indigenous cheese isolates belonging to species $L b$. casei and $L b$. plantarum were used in this study. Genotypic characterization (RAPD-PCR analysis) was used to identify these strains and the data was published by Skelin et al. (2012). Isolated lactobacilli proceeded from samples of fresh milk, fresh cheese and different stages of cheese ripening obtained from 3 independent family farms from Istria. Used strains were stored in glycerol at $-80{ }^{\circ} \mathrm{C}$ and activated in Brain Heart Infusion (Biolife, Milano, Italy) liquid medium before analysis.

\section{Survival in a simulated oral cavity}

In order to determine the ability of Lactobacillus strains to survive in simulated conditions in the oral cavity, a modified method described by Morandi et al., (2013) was used.

All strains were grown in $2 \mathrm{~mL}$ of MRS (Biolife, Milano, Italy) liquid medium with addition of $1.5 \%$ skim milk for $24 \mathrm{~h}$ at $30{ }^{\circ} \mathrm{C}$. Part of the overnight culture was diluted ten times in IX PBS buffer. A series of dilutions was made ranging from $10^{-1}$ to $10^{-5}$, and from $10^{-5}$ dilution, $100 \mu \mathrm{L}$ was applied to the MRS solid medium. Each strain was tested twice. The plates were incubated at $30^{\circ} \mathrm{C}$ for $48 \mathrm{~h}$ in anaerobic conditions.

Overnight cultures of the same portion were also diluted ten times in 1X PBS buffer, which was treated with $200 \mathrm{~mL}$ of lysozyme (100 ppm). The suspension was incubated $5 \mathrm{~min}$ at $30{ }^{\circ} \mathrm{C}$, after which the dilution $10^{-5}$ was plated on solid MRS medium. The tests were performed twice. The plates were incubated at $30{ }^{\circ} \mathrm{C}$ for $48 \mathrm{~h}$ in anaerobic conditions. The result is expressed as a proportion (\%) of surviving cells after exposure to simulated oral cavity, and is calculated using the formula:

$\%=$ (number of surviving colonies) $/$ (number of colonies) x 100

\section{Survival in simulated gastric \\ and intestinal conditions}

To determine the survival of Lactobacillus strains in simulated gastric and intestinal environment a modified methodology described by Dolereys et al. (2004) were used.

\section{Gastric test}

To test the ability of lactobacilli isolates to survive in the stomach, the gastrointestinal conditions were simulated by mixing $0.5 \% \mathrm{NaCl}$ and $0.3 \%$ pepsin (Sigma-Aldrich Co, USA) with the $\mathrm{pH} 2.5$, adjusted with $1 \mathrm{M} \mathrm{HCl}$. The solution was sterilized by filtration through a filter of $0.22 \mu \mathrm{m}$ pore size. 
One millilitre of overnight culture was centrifuged for $10 \mathrm{~min}$ at $10000 \mathrm{~g}$, after which the pellet was washed twice with $0.1 \%$ peptone water (Biolife, Milano, Italy) and resuspended in $100 \mathrm{~mL}$ of $0.1 \%$ peptone. Thirty millilitres of the lactobacilli suspension was transferred to $270 \mathrm{~mL}$ of the simulated gastric condition solution and incubated for $40 \mathrm{~min}$ at $30{ }^{\circ} \mathrm{C}$. One millilitre of the suspension (corresponding to dilution of -1) served to prepare a series of dilutions (ranging to $10^{-5}$ ), and $100 \mu \mathrm{L}$ of $10^{-5}$ dilution was applied to the solid MRS (Biolife, Milano, Italy) medium. Each strain was tested twice. The plates were incubated at $30{ }^{\circ} \mathrm{C}$ for $48 \mathrm{~h}$ in anaerobic conditions. The result is expressed as a percentage (\%) of surviving cells after exposure to simulated gastric conditions, and is calculated according to the formula mentioned above.

\section{Duodenal test}

To determine the ability of isolate's survival in duodenal environment, the solution that simulated those conditions were prepared by mixing $0.4 \%$ bile salts (Biolife, Milano, Italy) and $0.2 \%$ pancreatin (Sigma-Aldrich Co, USA). The methodology used in continuation was the same as previously described when gastric test was carried out. The results were obtained by analysing the number of surviving cells after exposure to simulated duodenal conditions, and are calculated according to the above formula.

\section{Autoaggregation assay}

The autoaggregation assay was performed according to the method previously described by Del Re et al., (2000) with certain modifications. The cells were harvested from overnight cultures grown in $6 \mathrm{~mL}$ of MRS (Biolife, Milano, Italy) medium at $37^{\circ} \mathrm{C}$. The cultures were centrifuged at $10000 \mathrm{~g}$ at $4{ }^{\circ} \mathrm{C}$ for $15 \mathrm{~min}$. The pellets were washed $2 \mathrm{ti}-$ mes and resuspended in phosphate buffered saline (PBS 1x). Absorbance was measured at $610 \mathrm{~nm}$ and the aimed cell concentration was of $\pm 10^{8} \mathrm{CFU} / \mathrm{mL}$. The cultures were vortexed and incubated at room temperature. The absorbance was measured at 0,3 and $5 \mathrm{~h}$ after the incubation. Autoaggregation was calculated according to the formula:

Autoaggregation $(\%)=\left(1-\left(A_{t} / A_{0}\right)\right) \times 100$

Where, $A_{t}$ represents the absorbance at time 3 and $5 \mathrm{~h}$ and $\mathrm{A}_{0}$ the absorbance at time 0 .

\section{Acidification activity}

One hundred $\mu \mathrm{L}$ of overnight isolate strains culture was passed to a sterile $20 \mathrm{~mL}$ of $10 \%$ skim milk solution. The samples were incubated at $30{ }^{\circ} \mathrm{C}$, and the $\mathrm{pH}$ was monitoring at 2, 6 and $24 \mathrm{~h}$. The ability of the investigated strains to acidify milk was expressed as the change in $\mathrm{pH}$ over time, according to Jamaly et al. (2010): $\Delta \mathrm{pH}=\mathrm{pH}$ (final value) $\mathrm{pH}$ (initial value).

\section{Proteolytic activity}

Proteolytic activity of examined Lactobacillus strains was measured using two different methods.

The Lactobacillus strains were grown in $5 \mathrm{~mL}$ of BHI (Biolife, Milano, Italy) liquid medium with $1.5 \%$ skim milk (Biolife, Milano, Italy) and were incubated for $24 \mathrm{~h}$ at $30^{\circ} \mathrm{C}$. One aliquot of $2 \mu \mathrm{L}$ of the overnight culture was plated directly into BHI agar with $1.5 \%$ skim milk and simultaneously, $10 \mu \mathrm{L}$ of respective culture was added on the sterile cellulose disc previously placed on the agar plates. The plates were incubated at $30{ }^{\circ} \mathrm{C}$ for $48 \mathrm{~h}$ in anaerobic conditions. Degradation of casein was determined by measuring the halos of decomposition around the disc as well as around directly applied cultures.

Proteolytic activity was also measured using a modified chromogenic method described by Savoy de Giori and Hébert, (2000). The measured concentration of released $p$-nitroanilide ( $p \mathrm{NA}$ ) from the peptide (S-Ala) was contributed to the proteinase activity of Lactobacillus strains. Investigated strains were grown in $50 \mathrm{~mL}$ of MRS (Biolife, Milano, Italy) liquid medium with 1.47 grams of $\mathrm{CaCl}_{2}$, and incubated at $37{ }^{\circ} \mathrm{C}$ until an optical density of 1.5 at $600 \mathrm{~nm}$ was reached. Then the cultures were centrifuged for $10 \mathrm{~min}$ at $10000 \mathrm{~g}$ at $4{ }^{\circ} \mathrm{C}$, after which the pellet was washed twice with a saline buffer composed of $10 \mathrm{mM} \mathrm{CaCl}_{2}$ and $0.8 \%$ sodium chloride. The cells were resuspended in $2.5 \mathrm{~mL}$ of $50 \mathrm{mM}$ Tris buffer with a $\mathrm{pH}$ of 7.8. Buffer containing $143.75 \mu \mathrm{L}$ of $0.2 \mathrm{M}$ phosphate buffer, $112.5 \mu \mathrm{L}$ of $5 \mathrm{M} \mathrm{NaCl}$ and $18.75 \mu \mathrm{L}$ of $20 \mathrm{mM}$ S-Ala (Sigma) was added to $100 \mathrm{~mL}$ of resuspended cells. The suspension was vortexed and incubated at $37^{\circ} \mathrm{C}$ for 30 minutes. The reaction was stopped by adding $87.5 \mathrm{~mL}$ of $80 \%$ acetic acid. The suspension was centrifuged for $5 \mathrm{~min}$ at $10000 \mathrm{~g}$. The amount of released $p$ NA was measured at $410 \mathrm{~nm}$. 
Quantity of released $p$ NA is calculated according to the formula:

$\mu \mathrm{M} p \mathrm{NA}=\varepsilon \times \Delta \mathrm{A}_{410} \mathrm{~F} \times 10^{3}$ where;

$\varepsilon=$ molar absorption coefficient, $8.800 / \mathrm{M} / \mathrm{cm}$

$\Delta \mathrm{A}_{410}=$ Measured absorbance at $410 \mathrm{~nm}$

$\mathrm{F}=$ dilution factor, calculated according to the formula: $\mathrm{F}=$ final volume/volume

\section{Lipolytic activity}

Lipolytic activity was evaluated on tributyrin agar (Acros Organics, Geel, Belgium) that was homogenized with $0.01 \%$ of tributyrin by ultrasound for $2 \mathrm{~min}$ at $20 \mathrm{kHz}$. One aliquot of $2 \mu \mathrm{L}$ of the overnight grown Lactobacillus cultures was plated directly into agar plates and simultaneously, $10 \mu \mathrm{L}$ of cultures' aliquot was added on the sterile cellulose disc previously placed on the tributyrin agar. The plates were incubated at $30{ }^{\circ} \mathrm{C}$ for $72 \mathrm{~h}$ in anaerobic conditions. Degradation of lipids was determined by measuring the halos of decomposition around the disc, as well as around the directly applied cultures.

\section{Antimicrobial activity}

The antimicrobial activity was performed using a modified method by Domig et al. (2014). The cheese strains, belonging to $L b$. plantarum and $L b$. case $i$ were compared to their ability to inhibit the growth of spoilage and food borne pathogens as followed: B1 (Bacillus cereus DSMZ 6791), B2 (Bacillus thuringiensis DSM2 2046T), B3 (Pseudomonas fluorescens WCS 417r), B4 (Serratia marcescens DSMZ 30121T), B5 (Escherichia coli JM 105), B6 (Staphylococcus aureus DSMZ 20231) and B7 (Listeria innocua ATCC33090).

Grown isolates of $L b$. plantarum and $L b$. casei were applied in two parallel lines, spaced $17 \mathrm{~mm}$ to one-another, in the centre of the Petri dish. Plates were incubated for 48 hours at $30{ }^{\circ} \mathrm{C}$ in anaerobic conditions. Target strains were grown in $5 \mathrm{~mL}$ of BHI liquid media and $5 \mu \mathrm{L}$ of culture was applied between the stretched lines of Lactobacillus, previously incubated. Target strains were also applied in the same amount on the edges of the Petri dish that served as a control. Plates were additionally incubated for $24 \mathrm{~h}$ aerobically at $30^{\circ} \mathrm{C}$ or $37^{\circ} \mathrm{C}$, depending on the type of referent strain used. The antimicrobial activity was determined by comparison of the size and density of grown target strains colonies in between lactobacilli lines, and those applied on the edges of the Petri dish, where target strains were not in contact with lactobacilli.

\section{Haemolytic activity}

Liquid Lactobacillus strains were plated on the solid BHI (Biolife, Milano, Italy) medium supplemented with $5 \%$ bovine blood (Acila AG, Mörfelden-Walldorf, Germany). The plates were incubated for $48 \mathrm{~h}$ on $30{ }^{\circ} \mathrm{C}$. Haemolytic activity was determined by visualisation and changes in colour of the medium.

\section{Results}

\section{Survival in simulated GIT conditions}

Ability of Lactobacillus strains to survive in a simulated oral and GIT environment was tested in laboratory conditions. Survival rate was species or even strain dependent, or depending on precise test applied (Table 1). The best survival properties were noticed for strains MLK 2-2, CH3/3/3 and $\mathrm{CH} 1 / 3 / 6$ for all three environments tested whereas strain $\mathrm{CH} 2 / 3 / 20$ were not able to survive in any of simulated conditions.

\section{Autoaggregation ability}

The investigated strains showed a weak ability to aggregate after $3 \mathrm{~h}$, and after $5 \mathrm{~h}$ of incubation. Percentage of autoaggregation of Lactobacillus strains are shown in Table 2.

\section{Proteolytic and lipolytic potential}

Based on the casein degradation, by using the disc diffusion method, Lactobacillus strains showed different proteolytic activity. Results of proteolytic (caseinolytic) activity were categorized into four groups based on the halo formation around the disc and around cultures applied directly into the agar medium: $(-)$ no halo observed, $(+)$ those with weak activity and halo size $<8 \mathrm{~mm},(++)$ those with moderate activity and halo size between $8-10 \mathrm{~mm}$ and $(+++)$ those with pronounced activity which halo size was $>10 \mathrm{~mm}$. The majority of strains exhibited pronounced caseinolytic activity; $\mathrm{CH} 2 / 3 / 7$, $\mathrm{CH} 2 / 2 / 3, \mathrm{CH} 1 / 3 / 9, \mathrm{CH} 1 / 3 / 4, \mathrm{CH} 1 / 3 / 6$, MLK 2-1 
Table 1. Survival ability of Lactobacillus strains in GIT conditions. Results are presented as percentage (\%) of survived cells after exposure to simulated oral cavity, intestine and gastric conditions

\begin{tabular}{|c|c|c|c|c|}
\hline \multirow[b]{2}{*}{ Strain label } & \multirow[b]{2}{*}{ Lactobacillus species } & \multicolumn{3}{|c|}{ Survival (\%) in simulated } \\
\hline & & Oral conditions & $\begin{array}{l}\text { Duodenal } \\
\text { conditions }\end{array}$ & $\begin{array}{c}\text { Gastric } \\
\text { conditions }\end{array}$ \\
\hline $\mathrm{CH} 3 / 0 / 1$ & Lb. plantarum & 85.33 & 100.00 & 0.00 \\
\hline $\mathrm{CH} 2 / 3 / 20$ & Lb. plantarum & 0.00 & 0.00 & 0.00 \\
\hline $\mathrm{CH} 2 / 3 / 7$ & Lb. plantarum & 40.00 & 24.00 & 33.00 \\
\hline $\mathrm{CH} 2 / 2 / 3$ & Lb. plantarum & 35.67 & 0.00 & 100.00 \\
\hline $\mathrm{CHl} / 3 / 1$ & Lb. casei & 86.84 & 46.27 & 53.73 \\
\hline $\mathrm{CHl} / 3 / 12$ & Lb. casei & 100.00 & 18.64 & 44.77 \\
\hline $\mathrm{CHl} / 3 / 9$ & Lb. plantarum & 52.78 & 47.83 & 52.17 \\
\hline $\mathrm{CH} 3 / 3 / 3$ & Lb. plantarum & 100.00 & 100.00 & 72.00 \\
\hline $\mathrm{CHl} / 3 / 4$ & Lb. casei & 50.00 & 46.15 & 25.64 \\
\hline $\mathrm{CHl} / 3 / 6$ & Lb. casei & 92.52 & 100.00 & 54.37 \\
\hline MLK 2-1 & Lb. plantarum & 88.29 & 100.00 & 2.90 \\
\hline MLK 2-2 & Lb. casei & 91.67 & 92.86 & 85.71 \\
\hline
\end{tabular}

Table 2. Autoaggregation ability of Lactobacillus strains. The average initial number of cells was $\pm 10^{8} \mathrm{CFU} / \mathrm{mL}$

\begin{tabular}{lccc}
\hline \multirow{2}{*}{ Strain label } & \multirow{2}{*}{$\begin{array}{c}\text { Lactobacillus } \\
\text { species }\end{array}$} & \multicolumn{2}{c}{ Autoagreggation (\%) } \\
\cline { 3 - 4 } & $\mathrm{h}$ h & $5 \mathrm{~h}$ \\
\hline $\mathrm{CH} 3 / 0 / 1$ & Lb. plantarum & 10.73 & 14.69 \\
\hline $\mathrm{CH} 2 / 3 / 20$ & Lb. plantarum & 15.56 & 16.73 \\
\hline $\mathrm{CH} 2 / 3 / 7$ & Lb. plantarum & 11.38 & 12.60 \\
\hline $\mathrm{CH} 2 / 2 / 3$ & Lb. plantarum & 11.89 & 20.00 \\
\hline $\mathrm{CH} 1 / 3 / 1$ & Lb. casei & 15.13 & 23.03 \\
\hline $\mathrm{CH} 1 / 3 / 12$ & Lb. casei & 9.55 & 15.17 \\
\hline $\mathrm{CH} 1 / 3 / 9$ & Lb. plantarum & 11.91 & 16.60 \\
\hline $\mathrm{CH} 3 / 3 / 3$ & Lb. plantarum & 13.64 & 18.94 \\
\hline $\mathrm{CH} 1 / 3 / 4$ & Lb. casei & 5.68 & 21.59 \\
\hline $\mathrm{CH} 1 / 3 / 6$ & Lb. casei & 11.89 & 14.10 \\
\hline $\mathrm{MLK} 2-1$ & Lb. plantarum & 16.05 & 17.90 \\
\hline $\mathrm{MLK} 2-2$ & Lb. casei & 16.14 & 16.67 \\
\hline
\end{tabular}

Table 3. Proteolytic activity of Lactobacillus strains

\begin{tabular}{ccc}
\hline Strain label & $\begin{array}{c}\text { Lactobacillus } \\
\text { species }\end{array}$ & $\begin{array}{c}\text { Proteolytic } \\
\text { activity }\end{array}$ \\
\hline $\mathrm{CH} 3 / 0 / 1$ & Lb. plantarum & + \\
\hline $\mathrm{CH} 2 / 3 / 20$ & Lb. plantarum & ++ \\
\hline $\mathrm{CH} 2 / 3 / 7$ & Lb. plantarum & +++ \\
\hline $\mathrm{CH} 2 / 2 / 3$ & Lb. plantarum & +++ \\
\hline $\mathrm{CH} / 3 / 1$ & Lb. casei & - \\
\hline $\mathrm{CH} 1 / 3 / 12$ & Lb. casei & - \\
\hline $\mathrm{CH} 1 / 3 / 9$ & Lb. plantarum & +++ \\
\hline $\mathrm{CH} 3 / 3 / 3$ & Lb. plantarum & + \\
\hline $\mathrm{CH} / 3 / 4$ & Lb. casei & +++ \\
\hline $\mathrm{CH} / 3 / 6$ & Lb. casei & +++ \\
\hline $\mathrm{MLK} 2-1$ & Lb. plantarum & +++ \\
\hline $\mathrm{MLK} 2-2$ & Lb. casei & +++ \\
\hline
\end{tabular}

$(-)$ no halo observed, $(+)$ halo size $<8 \mathrm{~mm},(++)$ halo size between $8-10 \mathrm{~mm}$, and $(+++)$ halo size $>10 \mathrm{~mm}$ 
and MLK 2-2. Only one strain had moderate caseinolytic activity; $\mathrm{CH} 2 / 3 / 20$ and weak caseinolytic activity was observed for two strains, $\mathrm{CH} 3 / 0 / 1$ and $\mathrm{CH} 3 / 3 / 3$. Strains $\mathrm{CHl} / 3 / 1$ and $\mathrm{CHl} / 3 / 12$ did not display caseinolytic activity (Table 3).

Proteolytic activity was also determined using a chromogenic method. The calculated amount of released chromogenic peptide $p \mathrm{NA}$, due to the enzymatic action of lactobacilli, is shown in Table 4 . The minimum of proteolytic activity was observed for isolate MLK 2-2 and it was $4477 \mu \mathrm{M} p \mathrm{NA}$, and the highest value was in isolate $\mathrm{CH1} / 3 / 4$ which was $7448.1 \mu \mathrm{M} p \mathrm{NA}$. Lipolytic potential was not notice for any of the Lactobacillus strains tested (data not shown).

\section{Acidification potential}

The ability of Lactobacillus strains to acidify milk is shown in Table 5 . The initial $\mathrm{pH}$ value of milk was of 6.34. The measurement was carried out in two replications, and the results are shown as mean values. From a total of 12 Lactobacillus isolates, 5 strains; $\mathrm{CH} 1 / 3 / 9, \mathrm{CH} 3 / 3 / 3, \mathrm{CH} 1 / 3 / 6$, MLK 2-1 and MLK 2-2, were able to lower the $\mathrm{pH}$ of milk to

Table 4. Proteolytic activity of Lactobacillus strains determined using a chromogenic method. Results are presented as $\mu \mathrm{M}$ of $p$ - nitroamilide $(p N A)$

\begin{tabular}{ccc}
\hline Strain label & Lactobacillus species & $\mu \mathrm{M} p \mathrm{NA}$ \\
\hline $\mathrm{CH} 3 / 0 / 1$ & Lb. plantarum & 4761.9 \\
\hline $\mathrm{CH} 2 / 3 / 20$ & Lb. plantarum & 5982.9 \\
\hline $\mathrm{CH} 2 / 3 / 7$ & Lb. plantarum & 5046.8 \\
\hline $\mathrm{CH} 2 / 2 / 3$ & Lb. plantarum & 5250.3 \\
\hline $\mathrm{CH} 1 / 3 / 1$ & Lb. casei & 5372.4 \\
\hline $\mathrm{CH} 1 / 3 / 12$ & Lb. casei & 4517.7 \\
\hline $\mathrm{CH} 1 / 3 / 9$ & Lb. plantarum & 4843.3 \\
\hline $\mathrm{CH} 3 / 3 / 3$ & Lb. plantarum & 5006.1 \\
\hline $\mathrm{CH} 1 / 3 / 4$ & Lb. casei & 7448.1 \\
\hline $\mathrm{CH} 1 / 3 / 6$ & Lb. casei & 4884.0 \\
\hline $\mathrm{MLK} 2-1$ & Lb. plantarum & 4477.0 \\
\hline $\mathrm{MLK} 2-2$ & Lb. casei & 7000.4 \\
\hline
\end{tabular}

5.00 , after 24 hours of incubation and showed moderate to strong acidification potential. According to Beresford et al. (2001), strains with $\Delta \mathrm{pH}$ in $24 \mathrm{~h}$ between 1 and 2 belong to the group of bacteria with moderate acidification ability while strains with $\Delta \mathrm{pH}$ in $24 \mathrm{~h} \geq 2$ are considered to be strong acidifiers.

\section{Antimicrobial potential and haemolysis}

The investigated lactobacilli were classified into 4 categories, based on their ability to limit the proliferation of food pathogens in terms of the reduction of the size and/or the density of target strain between the lines of Lactobacillus isolates, in comparison to those grown at the edge of the Petri dish as demonstrated in Domig et al. (2014). Those marked as (-) did not show any antimicrobial activity, $(+)$ is referred to weak antimicrobial activity/ weak reduction of the size and/or the density of target strain, $(++)$ was marked as medium antimicrobial activity, $(+++)$ as pronounced antimicrobial activity and $(++++)$ complete inhibition of target referent strains. Results of antimicrobial activity of the Lactobacillus isolates against target strains are shown in Table 6.

Table 5. Ability of Lactobacillus strains to acidify milk. The $\mathrm{pH}$ values were measured after 2, 6 and 24 hours of incubation

\begin{tabular}{ccccc}
\hline $\begin{array}{c}\text { Strain } \\
\text { label }\end{array}$ & $\begin{array}{c}\text { Lactobacillus } \\
\text { species }\end{array}$ & $\Delta \mathrm{pH}_{2 \mathrm{~h}}$ & $\Delta \mathrm{pH}_{6 \mathrm{~h}}$ & $\Delta \mathrm{pH}_{24 \mathrm{~h}}$ \\
\hline $\mathrm{CH} 3 / 0 / 1$ & Lb. plantarum & 0.03 & 0.05 & 1.06 \\
\hline $\mathrm{CH} 2 / 3 / 20$ & Lb. plantarum & 0.03 & 0.05 & 1.18 \\
\hline $\mathrm{CH} 2 / 3 / 7$ & Lb. plantarum & 0.03 & 0.08 & 0.32 \\
\hline $\mathrm{CH} 2 / 2 / 3$ & Lb. plantarum & 0.03 & 0.06 & 0.18 \\
\hline $\mathrm{CH} 1 / 3 / 1$ & Lb. casei & 0.02 & 0.06 & 0.21 \\
\hline $\mathrm{CH} 1 / 3 / 12$ & Lb. casei & 0.00 & 0.14 & 1.04 \\
\hline $\mathrm{CH} 1 / 3 / 9$ & Lb. plantarum & 0.04 & 0.05 & 1.46 \\
\hline $\mathrm{CH} 3 / 3 / 3$ & Lb. plantarum & 0.09 & 0.11 & 2.35 \\
\hline $\mathrm{CH} 1 / 3 / 4$ & Lb. casei & 0.03 & 0.07 & 0.35 \\
\hline $\mathrm{CH} 1 / 3 / 6$ & Lb. casei & 0.04 & 0.04 & 1.85 \\
\hline $\mathrm{MLK} 2-1$ & Lb. plantarum & 0.04 & 0.06 & 1.80 \\
\hline $\mathrm{MLK} 2-2$ & Lb. casei & 0.04 & 0.07 & 1.74 \\
\hline
\end{tabular}


Strains $\mathrm{CH} 3 / 0 / 1, \quad \mathrm{CH} 2 / 2 / 3, \quad \mathrm{CH} 1 / 3 / 1$, $\mathrm{CH} 1 / 3 / 6$ and MLK 2-2 showed none to moderate antimicrobial activity against to most target strains. Strains $\mathrm{CH} 2 / 3 / 20, \mathrm{CH} / 3 / 12$ and $\mathrm{CH} / / 3 / 4$ displayed moderate or pronounced antimicrobial activity against the majority of target bacteria.

Majority of the Lactobacillus isolates showed antimicrobial activity against Serratia marcescens, and none to poor antimicrobial activity against Staphylococcus aureus and Listeria innocua.

In the food industry the lack of haemolytic activity is one the main criteria in the selection for potential food starters (Giraffa, 1995; Hawaz, 2014). Lactobacilli as well as most members of the group LAB show no haemolytic activity (MunozAtienza et al., 2013). This was confirmed with Lactobacillus isolates from Istrian cheese, none of the isolates exhibited haemolytic activity (data not shown).

\section{Discussion}

Ripening of cheese is a complex biochemical process. It involves changes in both, physico-chemical and microbiological properties. Microbial interactions during ripening determine certain character- istics of the product, such as sensory properties and hygienic safety (Ahola et al., 2002). Since Istrian cheese is produced from raw ewe's milk it contains more complex microbiota from those produced with pasteurized milk (Fuka et al., 2013). There are four known groups of lactic acid bacteria (LAB) that are dominant during cheese ripening and that have major impact on characteristics of the ripened cheese; mesophilic lactobacilli, pediococci, enterococci and Leuconostoc. Since strains of Lactobacillus casei and Lactobacillus plantarum used in this study proceed from indigenous LAB group it was necessary to explore their technological and probiotic potential such to select for potential bioprotective, starter or even probiotic cultures. This was achieved by measuring their proteolytic, lipolytic and haemolytic activity besides their acidification ability and survival ability in simulated GIT conditions.

The Lactobacillus isolates tested in our study displayed moderate acidification capacity. However, 5 isolates lowered the milks $\mathrm{pH}$ below 5.00 $(\Delta \mathrm{pH}=2.35 ; 1.85 ; 1.80 ; 1.74 ; 1.46)$, indicating a higher acidification potential, that is similar to the results published by Anas and colleagues (2008). According to research published by Perez et al., (2003), Hidalgo-Morales et al., (2005) and Haddad et al., (2005) certain strains such as

Table 6. Antimicrobial activity of Lactobacillus strains based on Domig et al., (2014)

\begin{tabular}{|c|c|c|c|c|c|c|c|c|}
\hline $\begin{array}{l}\text { Strain } \\
\text { label }\end{array}$ & $\begin{array}{l}\text { Lactobacillus } \\
\text { species }\end{array}$ & $\begin{array}{c}\text { Bacillus } \\
\text { cereus }\end{array}$ & $\begin{array}{c}\text { Bacillus } \\
\text { thuringiensis }\end{array}$ & $\begin{array}{l}\text { Pseudomonas } \\
\text { fluorescens }\end{array}$ & $\begin{array}{c}\text { Serratia } \\
\text { marcescens }\end{array}$ & E. coli & $\begin{array}{c}\text { Staphylococcus } \\
\text { aureus }\end{array}$ & $\begin{array}{l}\text { Listeria } \\
\text { innocua }\end{array}$ \\
\hline $\mathrm{CH} 3 / 0 / 1$ & Lb. plantarum & - & - & - & - & ++ & - & ++ \\
\hline $\mathrm{CH} 2 / 3 / 20$ & Lb. plantarum & ++ & + & + & +++ & ++ & + & - \\
\hline $\mathrm{CH} 2 / 3 / 7$ & Lb. plantarum & + & + & - & + & + & + & + \\
\hline $\mathrm{CH} 2 / 2 / 3$ & Lb. plantarum & - & - & - & + & - & - & + \\
\hline $\mathrm{CHl} / 3 / 1$ & Lb. casei & - & - & - & + & - & - & - \\
\hline $\mathrm{CHl} / 3 / 12$ & Lb. casei & + & +++ & ++ & ++ & ++ & + & - \\
\hline $\mathrm{CHl} / 3 / 9$ & Lb. plantarum & + & - & + & ++ & + & - & - \\
\hline $\mathrm{CH} 3 / 3 / 3$ & Lb. plantarum & ++ & + & ++ & + & - & - & + \\
\hline $\mathrm{CHl} / 3 / 4$ & Lb. casei & +++ & + & + & ++ & + & + & - \\
\hline $\mathrm{CHl} / 3 / 6$ & Lb. casei & - & - & + & ++ & - & - & + \\
\hline MLK 2-1 & Lb. plantarum & ++ & - & + & + & - & - & - \\
\hline MLK 2-2 & Lb. casei & + & ++ & + & ++ & - & + & - \\
\hline
\end{tabular}

$(-)=$ no activity, $(+)=$ weak reduction of size and/or density, $(++)=$ medium reduction of size and/or density, $(+++)=$ pronounced reduction of size and/or density of target strain and $(++++)=$ no pathogen growth. 
Lb. reuteri, $L b$. plantarum and $L b$. casei, as well as other members of the genus Lactobacillus have a low acidification capacity. Furthermore, a study published by Cheriguene et al. (2006) and Akabanda et al. (2014) confirmed the higher acidification ability of Lactobacillus species, but only after $24 \mathrm{~h}$ post incubation, when the produced acid reaches the same quantities as those produced by Lactococcus species. Since Lactobacillus is a genus of LAB which is usually isolated from milk and cheese; hence the presence of different strains possesses different abilities of acidification (Carnerio Ratao, 2010). Although, Lactobacillus isolates that show low acidification capacity are not ideal candidates to be used as part of starter cultures, nevertheless they can take part in the development of flavour and texture, by proteolytic and lipolytic activity or by producing bacteriocins.

Our results indicated that all 12 tested isolates showed low or moderate proteolytic activity and no lipolytic activity, like previously stated in bibliography (Ljungh and Wadström, 2003; Jay et al., 2005; Hidalgo-Morales et al., 2005). Lactobacilli are generally known for their limited protease activity. Interestingly, the type of protease may vary within same genus (Haddadi et al., 2005). Hebert et al. (2000) reported that some of the Lactobacillus species can display high; while others exhibit weak proteolytic activity. Weak lipolytic activity and absence of proteolytic activity in Lactobacillus was published by Munoz-Atienza et al. (2013) as well.

Lactic acid bacteria have the capability of producing antimicrobial agents called bacteriocins. Bacteriocins have inhibitory activity (Daeschel, 1989; Bhattacharya and Das, 2010) which influences the growth of other pathogens and spoilage microorganisms. The genus Lactobacillus is known for its production of bacteriocins (Munoz-Atienza et al., 2013) which can be linked to their antagonistic ability to compete and to colonize GIT (Garriga et al., 1993; Šušković et al., 2010; Leboš Pavunc et al., 2013).

Our study of antimicrobial activity against 7 potentially spoilage or pathogenic species revealed that almost all isolates were able to inhibit proliferation of Serratia marcescens. Five isolates showed low antimicrobial activity against Staphylococcus aureus and Listeria innocua, while the other 7 isolates showed no activity against these two pathogens.
Herreros et al. (2003) observed that $S$. aureus and L. innocua were not affected in their proliferation by Lactobacillus isolates. The study from An as et al. (2008) suggested that Lactobacillus plantarum had antimicrobial activity against $S$. aureus. This variation in ability to inhibit the pathogen proliferation is species or strain specific and needs to be further studied.

Numerous studies have been carried out in order to determine the commercial application of Lactobacillus as probiotics and their survival during gastric transit (Lilly et al., 1965; Havenaar et al., 1992; Daly et al., 1998; Gregurek 1999; Fernandez et al., 2003; Soccol et al., 2010; Sabir et al., 2010; Jankovic et al., 2012; Beganović et al., 2013; Domig et al., 2014; Terzić-Vidojević et al., 2015). Our isolates showed a high percentage of survival in a simulated oral cavity and 5 isolates showed more than 90 percent survival in simulated duodenum conditions. Simulated gastric conditions disclosed much lower survival, with an exception of 3 isolates that have revealed more than $70 \%$ survival rate.

In addition, all isolates showed a low ability to aggregate after 5 hours of incubation; this diminishes their probiotic properties since the aggregation ability is associated with adherence properties of the cell (Li et al., 2015) which also challenges their ability to colonize the GIT.

One of the emphasized criterions in the selection of starter or probiotic cultures is the lack of haemolytic activity which implies non-virulence of the isolate and their safe use in food production (Anas et al., 2008). Haemolysis is not characteristic for genus Lactobacillus and our selected cheese isolates did not show any haemolytic activity (Maragkoudakisa et al., 2006; Hawaz, 2014; Munoz Atienza et al., 2013).

\section{Conclusions}

Obtained results from our study showed that Lactobacillus isolates from Istrian cheese displayed high survival rate in a simulated oral cavity and the duodenum while the survival rate of most examined Lactobacillus isolates in a simulated gastric conditions was much lower. Generally, all strains demonstrated antimicrobial activity against Serratia marcescens, with an exception of strain $\mathrm{CH} 3 / 0 / 1$. Certain 
strains e.g., $\mathrm{CH} 2 / 3 / 20, \mathrm{CH} 1 / 3 / 12$, SIR1/3/4 exhibited antimicrobial activity against majority of food spoilage and pathogens tested. Although autoaggregation rate for all strains was low, the tendency of this isolates to autoaggregate showed exponential growth in between 2 hours. Moderate to strong milk acidification ability within 24 hours of incubation was measured for several strains which contributed to their potential application as starter cultures. Additionally, all investigated isolates showed low or moderate proteolytic activity and absence of lipolytic activity. Haemolytic activity was not observed in any of the tested isolates, which states their safety application.

Because of their moderate or strong acidification ability, pronounced proteolytic activity as well as medium or pronounced antimicrobial activity against tested spoilage or pathogenic bacteria, four Lactobacillus strains, $\mathrm{CH} 3 / 3 / 3, \mathrm{CH} 1 / 3 / 6$, MLK2-1 and MLK2-2 should be further investigated. As no isolate was superior for all tested properties, combination of two or more strains may be the best promising strategy for the application as starter cultures.

\section{Autohtoni sojevi roda Lactobacillus izolirani iz Istarskog sira kao potencijalne starter kulture}

\section{Sažetak}

Tradicionalni Istarski sir proizvodi se od nepasteriziranog ovčjeg mlijeka, bez dodatka starter kultura. Prema tome, specifična aroma i tekstura Istarskog sira pripisuje se, uz ostale faktore, metaboličkim procesima autohtone mikroflore od kojih vrste roda Lactobacillus imaju ključnu ulogu. Karakterizacija i izbor autohtonih sojeva laktobacila može dovesti do potencijalnog korištenje odabranih sojeva kao starter, zaštitnih ili probiotičkih kultura. U ovom istraživanju željeli smo istražiti tehnološki i probiotički potencijal sojeva Lactobacillus plantarum i Lactobacillus casei izoliranih iz tradicionalnog Istarskog sira pomoću metoda koje određuju njihov proteolitički, kazeinolitički, lipolitički, antimikrobni i hemolitički potencijal, kao i njihovu sposobnost zakiseljavanja, autoagregacije i preživljavanja u simuliranim gastrointestinalnim uvjetima. Svih 12 reprezentativnih sojeva pokazuju nisku do umjerenu proteolitičku aktivnost te odsutnost lipolitičke i hemolitičke aktivnosti. Od 12 sojeva, 5 je pokazalo jaku sposobnost zakiseljavanja, spuštajući pH mlijeka ispod 5,00 nakon 24 sati inkubacije. Nadalje, gotovo svi izolati pokazuju antimikrobno djelovanje u odnosu na vrstu Serratia marcescens te slabo antimikrobno djelovanje u odnosu na Staphylococcus aureus i Listeria innocua. Istraživani sojevi pokazali su visoku prosječnu stopu preživljavanja u simuliranim uvjetima usne šupljine i dvanaesnika, dok je prosječna stopa preživljavanja u simuliranim želučanim uvjetima bila znatno niža. Nakon 5 sati inkubacije, autoagregacijska sposobnost svih istraživanih sojeva bila je niska.

\section{Ključne riječi: Istarski sir, Lactobacillus spp., starter kulture, antimikrobno djelovanje}

\section{References}

1. Ahola, A.J., Yli-Knuuttila, H., Suomalainen, T., Poussa, T., Ahlström, Meurman, J.H., Korpela, R. (2002): Short-term consumption of probiotic-containing cheese and its effect on dental caries risk factors, Archives of Oral Biology 47 (11), 799-804. doi: 10.1016/S0003-9969(02)00112-7

2. Akabanda, F., Owusu-Kwarteng, J., Tano-Debrah, K., Parkouda, C., Jespersen, L. (2014): The use of lactic acid bacteria starter culture in the production of Nunu, a spontaneously fermented milk product in Ghana, International Journal of Food Science, 2014 (721067).

3. Anas, M., Zinedine, B.A., Rizk, H.A., Eddine, H.J., Mebrouk, K. (2012): Screening of autochthonous Lactobacillus species from Algerian raw goats' milk for the production of bacteriocin-like compounds against Staphylococcus aureus, African Journal of Biotechnology 11 (20), 4595-4606.

4. Beganović, J., Kos, B., Leboš Pavunc, A., Uroić, K., Džidara, P., Šušković, J. (2013): Proteolytic activity of probiotic strain Lactobacillus helveticus M92, Anaerobe 20, 58-64. doi: 10.1016/j.anaerobe.2013.02.004

5. Beresford, T.P., Fitzsimons, N., Brennan, N.L. Cogan, T.M. (2001): Recent advances in cheese microbiology, International Dairy Journal 11 (4-7), 259-274. doi: 10.1016/S0958-6946(01)00056-5

6. Bhattacharay, S., Das, A., American J. (2010): Study of physical and cultural parameters on the bacteriocins produced by lactic acid bacteria isolated from traditional Indian fermented foods, American Journal of Food Technology 5 (2), 111-120. doi: 10.3923/ajft.2010.111.120 
7. Carneiro Ratao, I.M. (2010): Microbiological and chemical characterization of traditional cheese made from milk produced by the algarvian goat breed. Ph.D. thesis. Cranfield University.

8. Cheriguene, A., Chougrani, F., Bekada A.M.A., El Soda, M., Bensoltane, A. (2007): Enumeration and identification of lactic microflora in Algerian goats' milk, African J Biotechnol 6, 1854-1861. doi: 10.5897/AJB2007.000-2275

9. Claesson, M.J., Van Sinderen, D., O'Toole, P.W. (2007): The genus Lactobacillus - A genomic basis for understanding its diversity, FEMS Microbiology Letters 269 (1), 22-28. doi: 10.1111/j.1574-6968.2006.00596.x

10. Daeschel, M.A. (1989). Antimicrobial substances from lactic acid bacteria for use as food preservatives, Food Technology (USA) 43 (1), 164-167.

11. Daly, C., Fitzgerald, G.F., O'Connor, L., Davis, R. (1998). Technological and Health benefits of dairy starter cultures, International Dairy Journal 8 (3), 195-205. doi: 10.1016/S0958-6946(98)00042-9

12. Del Re, B., Sgorbati, B., Miglioli, M., Palenzona, D. (2000). Adhesion, autoaggregation and hydrophobicity of 13 strains of Bifidobacterium longum, Letters in Applied Microbiology, 31, 438-442. doi: 10.1046/j.1365-2672.2000.00845.x

13. Doleyres, Y., Fliss, I., Lacroix, C. (2004). Increased stress tolerance of Bifidobacterium longum and Lactococcus lactis produced during continuous mixed-strain immobilized-cell fermentation, Journal of Applied Microbiology 97 (3), 527-539. doi: 10.1111/j.1365-2672.2004.02326.x

14. Domig, K.J.H., Kiss, H., Petricevic, L., Viernstein, H., Unger, F., Kneifel, W. (2014): Strategies for the evaluation and selection of potential vaginal probiotics from human sources: an exemplary study, Beneficial Microbes 5 (3), 263 - 272. doi: 10.3920/BM2013.0069

15. El Soda, M., Madkor, S.A, Tong, P.S. (2000). Adjunct cultures: recent developments and potential significance to the cheese industry, Journal of Dairy Science 83 (4), 609-619. doi: 10.3168/jds.S0022-0302(00)74920-4

16. Fernández, M.F., Boris, S., Barbés, C. (2003). Probiotic properties of human lactobacilli strains to be used in the gastrointestinal tract, Journal of Applied Microbiology 94 (3), 449-455. doi: 10.1046/j.1365-2672.2003.01850.x

17. Fox, P.F., Cogan, T.M. (2004). Cheese Chemistry, Physics and Microbiology. Cheese: Chemistry, Physics and Microbiology (Vol. 1).

18. Fuka, M.M., Wallisch, S., Engel, M., Welzl, G., Havranek, J., Schloter, M. (2013). Dynamics of bacterial communities during the ripening process of different Croatian cheese types derived from raw ewe's milk cheeses, PLoS ONE 8 (11), 1-10. doi: 10.1371/journal.pone.0080734
19. Garriga, M., Hugas, M., Aymerich, T., Monfort, J.M. (1993). Bacteriocinogenic activity of lactobacilli from fermented sausages, The Journal of Applied Bacteriology 75, 142-148. doi: 10.1111/j.1365-2672.1993.tb02759.x

20. Giraffa, G. (1995). Enterococcal bacteriocins: their potential as anti-Listeria factors in dairy technology, Food Microbiology 12, 291-299. doi: 10.1016/S0740-0020(95)80109-X

21. Gregurek, Lj. (1999): Antimikrobno i antimutageno djelovanje probiotika, Mljekarstvo 49 (4), 255-260.

22. Haddadi, K., Moussaoui, F., Hebia, I., Laurent, F., Le Roux, Y. (2005): E. coli proteolytic activity in milk and casein breakdown, Reproduction Nutrition Development, EDP Sicence 45 (4), 485-496.

23. Havenaar, R., Huis In't Veld, M.J.H. (1992): Probiotics: a general view. Lactic acid Bacteria in Health and Disease (ed. B.J.B. Wood), Elsevier Applied Science Publishers, Amsterdam. 1, 151-170.

24. Hébert, E.M., Raya, R.R., Tailliez, P., de Giori, G.S. (2000). Characterization of natural isolates of Lactobacillus strains to be used as starter cultures in dairy fermentation, International Journal of Food Microbiology 59 (1-2), 19-27. doi: 10.1016/S0168-1605(00)00282-8

25. Herreros, M.A., Fresno, J.M., González Prieto, M.J., Tornadijo, M.E. (2003). Technological characterization of lactic acid bacteria isolated from Armada cheese (a Spanish goats' milk cheese), International Dairy Journal 13, 469-479. doi: 10.1016/S0958-6946(03)00054-2

26. Herreros, M.A., Sandoval, H., González, L., Castro, J.M., Fresno, J.M., Tornadijo, M.E. (2005). Antimicrobial activity and antibiotic resistance of lactic acid bacteria isolated from Armada cheese (a Spanish goats' milk cheese), Food Microbiology 22, 455-459. doi: 10.1016/j.fm.2004.11.007

27. Hidalgo-Morales, M., Robles-Olvera, V., García, H.S. (2005). Lactobacillus reuteri beta-galactosidase activity and low milk acidification ability, $\mathrm{Ca}$ nadian Journal of Microbiology, 51 (3), 261-267. doi: 10.1139/w04-134

28. Jamaly, N., Benjouad, A., Comunian, R., Daag E., Bouksaim, M. (2010): Characterization of Enterococci isolated from Moroccan dairy products, African Journal of Microbiology Research 4 (16), 1768-1774

29. Janković, T., Freece, J., Abram, M., Gobin, I. (2012): Aggregation ability of potential probiotic Lactobacillus plantarum strains, International Journal of sanitary Engineering Research 6 (1) 19-24.

30. Jay, J.M., Loessner, M.J., Golden, D.A. (2005): Modern Food Microbiology. Springer Science and Business Media, Inc. New York, USA., 149-169.

31. Leboš Pavunc, A., Kos, B., Beganović, J., Uroić, K., Bučan, D., Šušković, J. (2013): Antibiotic susceptibility and antimicrobial activity of autochthonous starter cultures as safety parameters for fresh cheese production, Mljekarstvo 63 (4), 185-194. 
32. Li, Q., Liu, X., Dong, M., Zhou, J., Wang, Y. (2015): Aggregation and adhesion abilities of 18 lactic acid bacteria strains isolated from traditional fermented food, International Journal of Agricultural Policy and Research 3 (2), 84-92.

33. Lilly, D.M., Stillwell, R.H. (1965): Probiotics: Growth-promoting factors produced by microorganisms, Science 147, 747-748. doi: 10.1126/science.147.3659.747

34. Ljungh, A., Wadström, T. (2003): Lactobacillus molecular biology: From genomics to probiotics, Caister Academic Press. Norfolk, UK., 18-21.

35. Maragkoudakis, P.A., Zoumpopoulou, G., Miaris, C., Kalantzopoulos, G., Pot, B., Tsakalidou, E. (2006). Probiotic potential of Lactobacillus strains isolated from dairy products, International Dairy Journal 16 (3), 189-199. doi: 10.1016/j.idairyj.2005.02.009

36. Mäyrä-Mäkinen, A., Bigret, M. (1998): Industrial use and production of lactic acid bacteria. In lactic acid bacteria, Microbiology and Functional Aspects (ed. Linn, S.M. Lloyd, S., Roberts, R.J.) 73-102. NY: Marcel Dekker.

37. Morandi, S., Silvetti, T., Brasca, M. (2013). Biotechnological and safety characterization of Enterococcus lactis, a recently described species of dairy origin, Antonie van Leeuwenhoek 103 (1), 239-249. doi: 10.1007/s10482-012-9806-z

38. Muñoz-Atienza, E., Gómez-Sala, B., Araújo, C., Campanero, C., del Campo, R., Hernández, P.E., Cintas, L. M. (2013). Antimicrobial activity, antibiotic susceptibility and virulence factors of lactic acid bacteria of aquatic origin intended for use as probiotics in aquaculture, BMC Microbiology 13, 15. doi: 10.1186/1471-2180-13-15

39. Mioč, B., Prpić, Z., Barać, Z., Vnučec, I. (2012): Istrian sheep - Croatian indigenous breed. Croatian association of sheep and goat breeders, Zagreb.

40. Mulc, D., Jurković, D., Duvnjak, G., Sinković, T., Daud, J., Lješić, N., Špehar, M., Dražić, M. (2011): Breed structure of sheep under selection control from 2009 to 2011. In: Annual report 2011, Breeding of Sheep, Goats and Small Animals, 9.

41. Pérez, G., Cardell, E., Zárate, V. (2003): Technological characterization of lactic acid bacteria from Tenerife cheese, International Journal of Food Science and Technology 38, 537-546. doi: 10.1046/j.1365-2621.2003.00696.x

42. Ribeiro, A.C., Ribeiro, S.D.A. (2010). Specialty products made from goat milk, Small Ruminant Research, 89(2-3), 225-233. doi: 10.1016/j.smallrumres.2009.12.048

43. Sabir, F., Beyatli, Y., Cokmus, C., Onal-Darilmaz,
D. (2010). Assessment of Potential Probiotic Properties of Lactobacillus spp., Lactococcus spp., and Pediococcus spp. strains isolated from kefir, Journal of Food Science 75 (9), 568-573. doi: 10.1111/j.1750-3841.2010.01855.x

44. Savoy de Giori, G., Hébert, E.M. (2000). Methods to determine proteolytic activity of lactic acid bacteria, Food microbiology protocols, Volume 14 of the series Methods in Biotechnology, 197-202. doi: 10.1385/1-59259-029-2:197

45. Sieladie, D.V., Zambou, N.F., Kaktcham, P.M., Cresci, A., Fonteh, F. (2011): Probiotic properties of Lactobacilli strains isolated from raw cow milk in the western highlands of Cameroon, Innovative Romanian Food Biotechnology 9 (12), 12-28.

46. Skelin, A., Mrkonjić Fuka, M., Čanžek Majhenič, A., Redžepović, S., Samaržija, D., Bogovič Matijašić, B. (2012): Phenotypic and genotypic characterization of indigenous Lactobacillus community from traditional Istrian ewe's cheese, Food Technology and Biotechnology 50 (3), 362-370.

47. Soccol, C.R., Vandenberghe, L.P.D.S., Spier, M.R., Medeiros, A.B.P., Yamaguishi, C.T., De Dea Lindner, J., Thomaz-Soccol, V. (2010). The potential of probiotics: A review, Food Technology and Biotechnology 48 (4), 413-434.

48. Šušković, J., Kos, B., Beganović, J., Leboš Pavunc A., Habjanič, K., Matošić, S. (2010): Antimicrobial activitythe most important property of probiotic and starter lactic acid bacteria, Food Technology and Biotechnology 48, 296-307.

49. Terzić-Vidojević, A., Leboš Pavunc, A., Tonković, K., Beganović, J., Strahinić, I., Kojić, M., Veljović, K., Golić, N., Kos, B., Čadež, N., Grgurek, LJ., Šušković, J., Raspor, P., Topisirović, LJ. (2015): Evaluation of autochthonous lactic acid bacteria as starter cultures for production of white pickled and fresh soft cheeses, LWT-Food Science and Technology 63 (1), 298-306. doi: 10.1016/j.lwt.2015.03.050

50. Vasiee, A.R., Tabatabaei Yazdi, F., Mortazavi, A., Edalatian, M.R (2014): Isolation, identification and characterization of probiotic Lactobacilli spp. from Tarkhineh, International Food Research Journal 21 (6), 2487-2492.

51. Wouters, J. T. M., Ayad, E. H. E., Hugenholtz, J., Smit, G. (2002). Microbes from raw milk for fermented dairy products, International Dairy Journal 12 (2-3), 91-109. doi: 10.1016/S0958-6946(01)00151-0 